\title{
UVJERENJA STUDENATA UČITELJSKOG STUDIJA I ZAPOSLENIH UČITELJA O INKLUZIVNOJ PRAKSI ${ }^{1}$
}

\author{
DEJANA BOUILLET ${ }^{1}$, VLATKA DOMOVIĆ ${ }^{2}$, SANELA IVANČEVIĆ ${ }^{3}$ \\ ${ }^{1}$ Učiteljski fakultet Sveučilišta u Zagrebu, ${ }^{2}$ Učiteljski fakultet Sveučilišta u Zagrebu, ${ }^{3}$ Osnovna škola Matije Gubca, \\ Zagreb, kontakt: dejana.bouillet@ufzg.hr
}

Primljeno: 13.04.2017.

Izvorni znanstveni rad

Prihvaćeno: 26.09.2017.

UDK: $371.15: 376.1-056.34$

Sažetak: Uvjerenja se odnose na sklop konceptualnih predodžbi koje uključuju opća znanja o pojavama, ljudima i događajima vezanim uz profesionalni kontekst. Ovaj je rad usmjeren na utvrđivanje razlika u uvjerenjima studenata prve, treće i pete godine učiteljskog studija te zaposlenih učitelja o odgojno-obrazovnoj inkluziji i poučavanju učenika s teškoćama, u svrhu utvrđivanja odgovora na pitanje mijenjaju li se i na koji način uvjerenja različitih skupina ispitanika o učenicima s teškoćama i njihovoj inkluziji u odgojno-obrazovni proces. Istraživanje je provedeno na uzorku 585 studenata učiteljskog studija i učitelja zaposlenih u osnovnim školama u Republici Hrvatskoj. Primijenjena je metoda metafora koja uključuje poznati objekt ili događaj kao konceptualno sredstvo za razjašnjenje kompleksnih pojmova ili situacija. Sudionici istraživanja dopunjavali su rečenice 'Inkluzija učenika s teškoćama u razvoju je kao .... jer ... ’i 'Poučavanje učenika s teškoćama u razvoju je kao ... jer ... '.

Utvrđeno je da u ukupnom uzorku većina ispitanika izražava inkluzivna uvjerenja jer su njihovi odgovori usmjereni na oblikovanje i podržavanje učenika s teškoćama. Međutim, kada je u pitanju proces poučavanja, udio ispitanika koji iskazuju inkluzivna uvjerenja se smanjuje.

Inkluzivna uvjerenja u najvećoj mjeri karakteriziraju studente 3. godine učiteljskog studija koji su netom bili uključeni u kolegij o inkluzivnoj pedagogiji, a u najmanjoj mjeri zaposlene učitelje. Ostale skupine studenata dijele gotovo ista profesionalna uvjerenja, što upućuje na nedovoljan doprinos inicijalnog obrazovanja i praktičnog iskustva na transformaciju od predprofesionalnih prema profesionalnim uvjerenjima o inkluzivnom obrazovanju.

Ključne riječi: odgojno-obrazovna inkluzija, učenici s teškoćama u razvoju, inicijalno obrazovanje učitelja, učitelji, uvjerenja, metafore

\section{UVOD}

Suvremeni se obrazovni sustavi temelje na načelu inkluzivnosti koje podrazumijeva potrebu transformiranja kulture, politika i praksi u odgojnoobrazovnim ustanovama, kako bi se prilagodile učenicima različitih karakteristika te uklonile prepreke koje ometaju njihov rast, razvoj i smisleno sudjelovanje u odgojno-obrazovnom procesu (Farkas, 2014). Radi se o višedimenzionalnom konceptu koji pridonosi punom uvažavanju ljudskih prava, socijalnoj pravdi i omogućuje jednake mogućnosti svima, afirmirajući socijalni model odnosa društva prema različitostima (Hornby, 2014). Inkluzivno obrazovanje odgovara na različite odgojno-obrazovne potrebe svih učenika, a temelji se na uklju- čivanju i ravnopravnom sudjelovanju svih dionika odgojno-obrazovnog procesa u životu odgojnoobrazovnih ustanova. Podrazumijeva pristajanje uz inkluzivnu politiku i inkluzivnu odgojno-obrazovnu praksu koja smanjuje isključenost u odgoju i obrazovanju po bilo kojoj osnovi (Okvir za poticanje $i$ prilagodbu iskustava učenja te vrednovanje postignuća djece i učenika s teškoćama, 2016).

Obrazovna inkluzija podrazumijeva kvalitetno obrazovanje za svu djecu, kojim se promiče pravo svakog djeteta da, bez obzira na njegovo fizičko, intelektualno, emocionalno, socijalno, jezično ili drugo stanje, bude uključeno u odgojno-obrazovni sustav, odnosno u redovite škole (Karamatić Brčić, 2013). Inkluzivno obrazovanje je proces koji se pro-

1 Rad je dio znanstvenog projekta Razvoj profesionalnog identiteta tijekom inicijalnog obrazovanja učitelja koji se uz potporu Sveučilišta u Zagrebu realizira na Učiteljskom fakultetu Sveučilišta u Zagrebu. 
vodi kontinuirano i usmjeren je na potrebu novih metoda i oblika rada, koji su usmjereni na uvažavanje mogućnosti svakog djeteta. Inkluzivan nastavni program je primjeren i prilagođen svakom učeniku. Pristup je individualan, što iziskuje od učitelja da učenje prilagođava djetetovim mogućnostima, postavlja jasne granice i očekivanja, ispituje na način u kojem se očekuje i postiže uspjeh, razumije djetetove potrebe i ponašanja te njegov način komunikacije, osigurava pozivno prihvaćanje učenika, osigurava prilike za vježbanje socijalnih vještina, stvara prilike za odgovorno ophođenje s vršnjacima i odraslima, omogućuje razvoj pozitivne slike o sebi, stvara kod djeteta osjećaj prihvaćenosti, uočava socijalne vještine, razvija empatiju i stvara uvjete u kojima učenici osjećaju privrženost školi (Zrilić, 2011).

Kada je riječ o obrazovanju učenika s teškoćama u razvoju, učitelji su suočeni s mnogim profesionalnim izazovima. Njihova je ključna zadaća uspostaviti sklad između sposobnosti učenika s teškoćama u razvoju i sastavnica kurikula (Karamatić Brčić, 2013) te oblikovati poticajno odgojno-obrazovno okruženje koje će raznovrsnošću obrazovnih aktivnosti i socijalnih iskustava omogućiti uključenost učenika s teškoćama u sve aspekte školskog života (Ivančić i Stančić, 2013). Na podršku koju učenici s teškoćama dobivaju od svojih učitelja nadovezuju se ostali mehanizmi podrške uključivanja djece s teškoćama u razvoju u redovite škole, kao što su minimiziranje prepreka inkluzivnom procesu (smanjivanje predrasuda, uklanjanje arhitektonskih barijera i dr.), kvalitetno inkluzivno obrazovanje odgojno-obrazovnih radnika, senzibiliziranje učenika i njihovih roditelja na potrebe i prava djece $\mathrm{s}$ teškoćama te kontinuirana podrška članova stručnog tima škole učenicima s teškoćama (Dmitrović, 2011). Zrilić (2011) uz inkluzivno obrazovanje vezuje pozitivan odnos dionika odgojno-obrazovnog procesa prema različitostima, prihvaćanje individualnih potreba sve djece i poticanje interakcija među učenicima, odnosno fleksibilnost, prilagođavanje i angažiranost voditelja odgojno-obrazovnog procesa uz odgovarajuće materijalno-prostorne i druge uvjete.

\section{Uloga učitelja u inkluzivnoj praksi}

U ostvarivanju uspješne inkluzivne prakse ključnu ulogu imaju kompetentni učitelji s pri- mjereno razvijenim profesionalnim identitetom. Oni uspijevaju afirmirati prava svakog djeteta na najbolje moguće obrazovanje, unatoč izazovima i preprekama. Kompetentni učitelji razumiju da je inkluzivna filozofija polazište svakog odgojnoobrazovnog procesa pa uspješno poučavaju svu djecu, neovisno o njihovim obilježjima i materijalnim okolnostima u kojima se poučavanje odvija. Inkluzivni učitelj ne temelji svoju nastavu na pedagoškoj praksi u kojoj svi učenici uče na jednak način već im nudi više različitih opcija koje su dostupne svima. On odbacuje koncept inkluzivne pedagogije koji se temelji na zadovoljavanju potreba većine uz puko dodavanje nečeg drugačijeg za učenike s teškoćama, već proširuje, odnosno obogaćuje uobičajeno, kako bi bilo dostupno svim učenicima (Spratt i Florin, 2013).

Kvaliteta inkluzivnog djelovanja učitelja ovisi o prihvaćajućim stavovima, uvjerenjima, razvijenim vještinama i znanju, odnosno o njihovim kompetencijama (Batarelo Kokić, Vukelić i Ljubić, 2009). Međutim, istraživanja kontinuirano pokazuju da zaposleni učitelji ne posjeduju dostatne kompetencije za rad s djecom s teškoćama, te da studenti - budući učitelji smatraju da nisu dovoljno kompetentni za inkluzivnu praksu (Vizek Vidović, 2005; Domović, 2006; Skočić Mihić i sur., 2014; Bouillet i Bukvić, 2015; Domović, Vizek Vidović i Bouillet, 2017).

Miles (2007) ovakve procjene objašnjava strahom, nedostatnim znanjem i neinformiranosti učitelja o djeci s teškoćama, što pridonosi njihovoj nedovoljnoj prihvaćenosti na svim razinama - kako među učiteljima, tako među roditeljima i vršnjacima. Sve navedeno rezultira niskim očekivanjima, pristranosti i svojevrsnim samoispunjavajućim proročanstvom, što u konačnici pridonosi jačanju uvjerenja o nemogućnosti ostvarivanja inkluzivnog odgojno-obrazovnog procesa. Riječ je o uvjerenima da pripadnici određenih manjinskih grupa (u ovom slučaju - djece s teškoćama u razvoju) nemaju jednake mogućnosti i sposobnosti pa se od njih napredak ni ne očekuje. Na to se nadovezuju uvjerenja i postupci kojima se ta djeca zbog identiteta djeteta s teškoćom u razvoju, a koji se smatra inferiornim, dovode u nepovoljniji položaj, što sve zajedno rezultira neprimjerenim ponašanjem odgojno-obrazovnih djelatnika prema učenicima 
s teškoćama u razvoju i niskim obrazovnim postignućima te djece (Brajković i Milinović, 2015). Stoga ne iznenađuje da u obrazovanju još uvijek postoje velike nejednakosti u pristupačnosti obrazovanja djeci s teškoćama u razvoju, koja su još uvijek suočena s mnogim preprekama u ostvarivanju njihovog prava na obrazovanje. Bouillet $\mathrm{i}$ Kudek Mirošević (2015) svojim su istraživanjem utvrdile da učenici s teškoćama u razvoju u hrvatskim školama ne postižu očekivanu razinu socijalizacije i akademskog uspjeha te da unatoč mnogim teškoćama koje tijekom obrazovnog procesa manifestiraju, ne primaju odgovarajuću stručnu pomoć i podršku. Na to se nadovezuju rezultati istraživanja kojeg su provele Igrić, Cvitković i Wagner Jakab (2009), a pokazuju da učenici, roditelji i učitelji učenike s teškoćama procjenjuju nepovoljnije no što je to slučaj s tipično razvijenim učenicima. Autorice zaključuju da je teškoća djeteta velika prepreka roditeljima, učiteljima i vršnjacima u jednakom prihvaćanju te je stoga potrebno i dalje intenzivno raditi na razvoju inkluzivnih stavova i uvjerenja svih sudionika odgoja i obrazovanja djece s teškoćama u razvoju.

Slijedom rezultata prikazanih i brojnih drugih istraživanja, mnogi autori sumnjaju u resurse redovnih škola za poučavanje svih učenika (Forlin, 2012; Horby, 2014). U tom smislu, Romstein i Sekulić-Majurec (2015) s kvalitetom inkluzivnog procesa povezuju povoljniji omjer djece i odraslih, bolju diferencijaciju nastavnih sadržaja te dominaciju individualiziranog pristupa učeniku, uz korištenje specifičnih didaktičkih, audio-vizualnih sredstava i pomagala koja je za sada prepoznatljiva u posebnim, ali ne i u redovnim školama.

\section{Uloga inicijalnog obrazovanja učitelja u inkluzivnoj praksi}

Budući da je Republika Hrvatska potpisnica Konvencije UN-a o pravima djeteta (1990) i Konvencije UN-a o pravima osoba s invaliditetom (2007), inkluzivna načela poučavanja trebala bi biti temeljno polazište svakog obrazovnog procesa, uključujući inicijalno obrazovanje učitelja. Ono bi trebalo omogućiti usvajanje inkluzivnih uvjerenja i razvoj kompetencija za provedbu inkluzivne odgojno-obrazovne prakse u kojoj različitost među učenicima neće biti doživljeni kao prepreka, već kao poticaj u učenju i kreiranju odgojno-obrazovnog procesa. Istraživanja, međutim, potvrđuju da visokoškolske ustanove za inicijalno obrazovanje učitelja nisu dovoljno usmjerene ostvarivanju ove sastavnice studijskih programa jer tijekom studija učitelji ne stječu dovoljno kompetencija za poučavanje učenika s teškoćama (Skočić Mihić, 2011), pri čemu učitelji i nastavnici procjenjuju da su najmanje znanja i vještina tijekom inicijalnog obrazovanja stekli za rad s učenicima s teškoćama u učenju, učenicima s emocionalnim teškoćama i problemima u ponašanju (Vizek Vidović, 2005). Zrilić i Brzoja (2013) su utvrdili da postoje razlike u mišljenjima zaposlenih učitelja (učitelja s radnim iskustvom) i studenata učiteljskih fakulteta. Pri tome su studenti pete godine pokazali povoljnije stavove o inkluzivnoj praksi i procijenili se kompetentnijima u usporedbi s učiteljima. Skočić Mihić i sur. (2014) su na uzorku studenata Učiteljskog studija u Rijeci pokazali da se studenti osjećaju spremnima za prilagođavanje učionice i materijala za učenje, dok se za izravan rad s djecom s teškoćama u razvoju osjećaju osrednje kompetentno. Bouillet i Bukvić (2015) svojim istraživanjem upućuju na značajne razlike studenata različitih godina učiteljskih studija i zaposlenih učitelja u mišljenjima o obrazovnoj inkluziji učenika s teškoćama, pri čemu su mišljenja studenata završne godine studija i zaposlenih učitelja nepovoljnija u odnosu na studente prve i treće godine studija.

Način na koji se profesionalna uvjerenja i stavovi učitelja razvijaju, što podrazumijeva i razvoj uvjerenja i stavova o inkluziji, značajno ovisi o njihovoj profesionalnoj socijalizaciji tijekom njihova inicijalnog obrazovanja i trajnog profesionalnog razvoja. S time u vezi neki autori naglašavaju da profesionalna socijalizacija učitelja ima više etapa. Tako, na primjer, Zeichner i Gore (1990) opisuju profesionalnu socijalizaciju učitelja kao trostupanjski proces. On započinje s obrazovnim iskustvima koje su učitelji doživjeli kao učenici, dakle prije formalnog obrazovanja (prethodna ili anticipativna socijalizacija). Nakon toga slijedi period inicijalnog obrazovanja učitelja te razvoj tijekom njihovog rada u školi.

Inicijalno obrazovanje, odnosno formalno školovanje, može se smatrati početkom razvoja profesionalnog identiteta. Međutim, u inicijalnom obrazovanju učitelja se često naglašava samo ovladavanje znanstvenom disciplinom/predmetom koji 
se poučava i nastavnim vještinama, a mnogo se manje kao zadaća inicijalnog obrazovanja ističe razvoj profesionalnog identiteta koji uključuje profesionalne vrijednosti i uvjerenja (Sutherland i Markauskaite, 2012; Rogers, 2011; Beauchamp i Lynn, 2009; Feimen-Nemser, 2001). Takav pristup može utjecati na kasnije praktično profesionalno djelovanje učitelja, što potkrepljuju nalazi istraživanja u području inicijalnog obrazovanja učitelja koji upozoravaju na to da uspješnost budućih učitelja ne ovisi samo o stjecanju specifičnih vještina već i o ranoj profesionalnoj socijalizaciji tijekom inicijalnog obrazovanja (Feiman - Nemser, 2001; Domović i Vizek Vidović, 2013).

Pri tom se kao ključni zadaci profesionalne socijalizacije učitelja tijekom inicijalnog obrazovanja navode razvoj svijesti o kompleksnosti učiteljske uloge te postupna zamjena intuitivnih shvaćanja o prirodi učenja i poučavanja novim profesionalnim uvjerenjima i vrijednostima. Drugim riječima, uz posjedovanje profesionalnih znanja i vještina, kvaliteta profesionalnog djelovanja učitelja je određena i njihovim profesionalnim uvjerenjima.

Uvjerenja učitelja se mogu razumjeti kao sklop konceptualnih predodžbi koje uključuju opća znanja o pojavama, ljudima i događajima vezanim uz profesionalni kontekst. Ona se obično definiraju kao razumijevanja ili pretpostavke koje učitelji smatraju istinitima, pa stoga služe kao filter kroz koji se nova znanja i iskustva selektiraju (Zheng, 2009), odnosno sustav uvjerenja služi kao osobni vodič koji pomaže pojedincima da definiraju i razumiju svijet i sebe same (Pajeras, 2009). Budući da profesionalna uvjerenja u značajnoj mjeri mogu odrediti kako će se učitelji ponašati i kako će poučavati, važno je utvrditi kakva profesionalna uvjerenja imaju studenti na učiteljskim fakultetima, kao i već zaposleni učitelji. Uvjerenja se velikim dijelom temelje na osobnom iskustvu i emocionalno su obojena, vrlo su trajna i duboko ukorijenjena te mogu odolijevati racionalnim argumentima $i$ znanstvenim dokazima koji im mogu proturječiti. Drugim riječima, moguće je da nepostojanje adekvatnih profesionalnih uvjerenja sprečava razvoj kompetencija učitelja. Pritom su osobito važna uvjerenja o učeniku i učenju koja se odnose na shvaćanje o prirodi sposobnosti učenika i njihovom kapacitetu za učenje (Domović, 2011).

\section{PROBLEM, CILJEVI I HIPOTEZE ISTRAŽIVANJA}

Problem na koji se želi odgovoriti istraživanjem čiji su rezultati prikazani u ovom radu je odgovoriti na pitanje mijenjaju li se i na koji način uvjerenja studenata učiteljskog studija i zaposlenih učitelja o poučavanju učenika s teškoćama u razvoju i njihovoj inkluziji u odgojno-obrazovni proces. Iz tako definiranog problema proizlaze sljedeći ciljevi istraživanja:

1. Utvrditi uvjerenja studenata različitih godina studija i zaposlenih učitelja o inkluziji učenika $\mathrm{s}$ teškoćama,

2. Analizirati razlike u uvjerenjima između četiri skupine ispitanika (studenata prve, treće i pete godine učiteljskog studija te zaposlenih učitelja).

U skladu s postavljenim ciljevima i polaznom pretpostavkom da inicijalno obrazovanje i praktičan rad s djecom s teškoćama pridonosi profesionalnim uvjerenjima o odgojno-obrazovnoj inkluziji, postavljene dvije hipoteze. To su:

$\mathbf{H}_{1}$ - Zaposleni učitelji u usporedbi sa studentima imaju uvjerenja koja su u većoj mjeri usklađena sa znanstvenim spoznajama i strateškim preporukama o inkluziji učenika s teškoćama u redovne škole.

$\mathbf{H}_{2}$ - Studenti viših godina studija u usporedbi s mlađim kolegama imaju uvjerenja koja su u većoj mjeri usklađena sa znanstvenim spoznajama i strateškim preporukama o inkluziji učenika s teškoćama u redovne škole.

Hipoteze se temelje na postojećoj stručnoj literaturi i znanstvenim spoznajama o utjecaju primjerenog inicijalnog obrazovanja na stavove o inkluzivnoj praksi (npr. Skočić Mihić, 2011; Bouillet i Bukvić, 2015, Domović, Vizek Vidović i Bouillet, 2017).

\section{METODE ISTRAŽIVANJA}

\section{Sudionici istraživanja}

Podaci za ovo istraživanje su prikupljeni tijekom 2015. godine na uzorku od 585 ispitanika. To su studenti prve, treće i pete godine Učiteljskog fakulteta u Zagrebu te učitelji zaposleni u različitim osnovnim školama u Republici Hrvatskoj (u 
Varaždinskoj, Zagrebačkoj i Splitsko-dalmatinskoj županiji i gradu Zagrebu). Broj studenata prve godine je $157(26,8 \%)$, studenata treće godine $192(32,8 \%)$, studenata pete godine $102(17,4 \%)$ te zaposlenih učitelja 134 (22,9\%). Velika većina ispitanika (94\%) je ženskog spola.

Ovako konstruiran uzorak istraživanja omogućuje praćenje doprinosa stečenih kompetencija i iskustva ispitanika u području inkluzivnog obrazovanja, budući da se studenti prve godine nalaze na početku obrazovanja za učiteljsku profesiju i nemaju specifičnih kompetencija u ovom području, dok su studenti treće godine stekli određene kompetencije studiranjem kolegija Inkluzivna pedagogija. Studenti pete godine nalaze se u završnoj fazi inicijalnog obrazovanja pa su stekli znanja, vještine i sposobnosti kojima su namijenjeni kolegiji obuhvaćeni studijskim programom. Subuzorak učitelja čine učitelji koji su se školovali prema različitim studijskim programima, ali imaju iskustva u obrazovnoj inkluziji učenika s teškoćama u razvoju (njihovo prosječno radno iskustvo iznosi 6 godina).

\section{Prikupljanje i obrada podataka}

U ovome su istraživanju mišljenja studenata i učitelja ispitana pomoću kvalitativne metode, uporabom tehnike metafora. Metafora uključuje poznati objekt ili događaj kao konceptualno sredstvo za razjašnjenje kompleksnih pojmova ili situacija. $U$ obrazovnom kontekstu metafore se koriste kao analitičko sredstvo za istraživanje složenih iskustava i temeljnih uvjerenja. Logika upotrebe metafora je korištenje poznatog objekta ili događaja kao mentalnog sredstva za tumačenje pojmova i situacije koje dovode do novih spoznaja. Tako se metafore mogu razumjeti kao iskustvo psihološkog modeliranja koje vodi novim formama konceptualnih uvida (Domović i Vizek Vidović, 2013).

Sukladno gore navedenom, formulirane su dvije čestice otvorenog tipa koje su usmjerene ispitivanju shvaćanja studenata i zaposlenih učitelja o inkluziji i poučavanju učenika s teškoćama u razvoju. Sadržaj čestica formuliran je na sljedeći način:

- Inkluzija učenika s teškoćama u razvoju je kao... zato što...

- Poučavanje učenika s teškoćama u razvoju je kao...zato što....
U analizi metafora korišten je kvalitativni pristup poznat kao induktivna tematska analiza (Braun i Clarke, 2006). Sukladno tome, analiza metafora je u ovom istraživanju obuhvatila sljedeće faze i aktivnosti:

- upoznavanje s podatcima - čitanje navoda ispitanika više puta, uočavanje obrazaca ili sličnosti, bilježenje ideja od strane istraživača

- razvrstavanje inicijalnih obrazaca - sustavno sortiranje podataka po određenim obilježjima, temeljem uvida istraživača

- određivanje kategorija (tema) - usuglašeno određivanje potencijalnih kategorija (tema) i imenovanje kategorija

- pregledavanje kategorija (tema) - utvrđivanje sukladnosti kategorija (tema) i učestalosti pojavljivanja odgovora u pojedinoj kategoriji

- analiza zastupljenosti pojedinih kategorija u četiri skupine ispitanika

- interpretacija dobivenih podataka.

\section{REZULTATI I RASPRAVA}

Rezultati istraživanja obuhvaćaju prikaz deriviranih kategorija metafora te deskriptivan uvid u zastupljenost pojedinih kategorija u četiri skupine ispitanika (studenata različitih godina studija i zaposlenih učitelja). Postojanje statistički značajnih razlika među skupinama provjereno je izračunom vrijednosti i statističke značajnosti $\chi^{2}$ testa.

Slijedeći opisane korake $u$ analiziranju metafora, za svako je pitanje definirano sedam kategorija. Kategorije su formirane prema uvjerenjima o dominantnoj ulozi učitelja u inkluzivnom procesu, a kreću se od podržavanja učenika s teškoćama u razvoju do odbacivanja inkluzivne ideje zbog njezine neostvarivosti u postojećem obrazovnom sustavu.

U tablici 1 prikazane su kategorije derivirane iz metafora prikupljenih rečenicom Inkluzija učenika s teškoćama u razvoju je kao ... zašto što ...., uz navođenje primjera metafora za svaku kategoriju.

Kao što iz podataka prikazanih u tablici 1. proizlazi, u kategoriju Podržavanje grupirane su metafore koje upućuju na podršku inkluzivnom procesu koja se očituje u shvaćanju inkluzije kao uobičajene karakteristike obrazovnog procesa i sastavni dio učiteljske profesije, odnosno priliku da učitelji 
Tablica 1. Kategorije i primjeri metafora usmjereni na inkluziju učenika s teškoćama u razvoju

\begin{tabular}{|c|c|}
\hline \begin{tabular}{|l} 
Kategorija \\
(tema)
\end{tabular} & Metafora „Inkluzija učenika s teškoćama u razvoju je kao ... zašto što ...“ \\
\hline Podržavanje & $\begin{array}{l}\text { Ispit znanja zato što učitelji svo svoje skupljeno znanje u životu trebaju znati primjenjivati u posebnoj situaciji } \\
\text { nego inače. } \\
\text { Dar zato što omogućuje onima s teškoćama da budu također obrazovani kao i drugi. } \\
\text { Botanički vrt zato što je mnogo različitosti, ali su svi kao jedan. } \\
\text { Pronalaženje novog planeta za život zato što bez nje tisuću djece (u prenesenom značenju) umre. } \\
\text { Putovanje svijetom zato što uvijek otkrivamo nove stvari. }\end{array}$ \\
\hline \begin{tabular}{|l|} 
Oblikovanje \\
\end{tabular} & $\begin{array}{l}\text { Kruh zato što miješanjem različitih žitarica dobijemo bolji kruh. } \\
\text { Stavljanje začina u hranu zato što su začini potrebni da bi jelo bilo finije, začin bez hrane nema neku svrhu i } \\
\text { obrnuto. } \\
\text { Dodavanje nove boje jednobojnoj slici zato što svaki učenik s poteškoćama u razvoju može bitno oplemeniti } \\
\text { svoje suučenike i njihov način pogleda na svijet i ljude. } \\
\text { Igra memory ili puzzle, zato što učenika s teškoćama treba uključiti u šaroliku sliku sastavljenu od puzzle-a. } \\
\text { Gradnja kuće, zato što je svaki dio posla važan i bez njega ne bi ništa funkcioniralo. }\end{array}$ \\
\hline $\begin{array}{l}\text { Pružanje } \\
\text { pomoći }\end{array}$ & $\begin{array}{l}\text { Štaka, zato što pomaže, a pogotovo poštuje mogućnosti, i što se može najbolje izvući iz toga. } \\
\text { Prijateljstvo, zato što vlada poštovanje, zajedništvo, spremnost na pomoć. } \\
\text { Udomljavanje napuštenog mačića, zato što ćeš mu pružiti ljubav i potporu, a zauzvrat ćeš dobiti neizmjernu } \\
\text { zahvalnost i ljubav. } \\
\text { Poseban dar, nema ničeg ljepšeg u životu nego pomoći drugome da se razvije. } \\
\text { Obiteljska zajednica u kojoj je nekim članovima potrebna pojačana pomoć i potpora. }\end{array}$ \\
\hline Zaštita & $\begin{array}{l}\text { Susret mačke i pasa zato što su mačke slabije. } \\
\text { Stavljanje mrava među slonove zato što treba dodatna pažnja i ljubav da se osjeća kao i ostali - normalan. } \\
\text { Sadnja cvijeta među velikim drvećem zato što se baš poput cvijeta moraju boriti za opstanak, iako su jednako } \\
\text { vrijedni. } \\
\text { Bubamara među pčelama zato što je bubamara nježna i krhka, kao dijete s teškoćama u razvoju kojemu treba } \\
\text { više pažnje i ona se pokušava uklopiti među tu masu (pčele) s rizikom hoće li ju ona prihvatiti ili ne. } \\
\text { Ljubav zato što se stvara uzajamna veza i povjerenje koje djetetu olakšava napredovanje. }\end{array}$ \\
\hline $\begin{array}{l}\text { Ula } \\
\text { nap }\end{array}$ & $\begin{array}{l}\text { Velika nepoznanica zato što zahtjeva puno truda i istraživanja da bi se donijele konačne odluke i otkrilo neko } \\
\text { rješenje. } \\
\text { Hodanje kroz gustu maglu zato što je vrlo teško uputiti djecu u rad, no uz dovoljan trud i to je moguće. } \\
\text { Borba s vjetrenjačama zato što naizgled nemoguće, no trudom se učimo djelovati zajedno. } \\
\text { Prihvaćanje crne ovce u stado zato što su drugačiji od ostalih i potreban je veći napor za njihovo prihvaćanje } \\
\text { među ostale. } \\
\text { Klupko s čvorićima, zato što želimo da to ide glatko i da svi sudjeluju u tome, ali uvijek postoje neke prepreke. }\end{array}$ \\
\hline Neizvjesnost & $\begin{array}{l}\text { Dvosjekli mač zato što može olakšati, ali i otežati interakciju sa drugim učenicima zbog posebnog odnosa } \\
\text { učitelja prema njemu. } \\
\text { Luda vožnja zato što nikada ne znaš kako će završiti. } \\
\text { Dodavanje teksta u već napisanu knjigu zato što u razredu imamo cjelinu i dodavanjem djeteta s poteškoćama } \\
\text { riskiramo, no to može značiti da će ta cjelina postati još bolja ili možda lošija. } \\
\text { Put u nepoznato zato što bez obzira na pripreme, rezultat nas uvijek može iznenaditi - može doći do mnogih } \\
\text { teškoća, ali i velikog napretka. } \\
\text { Kolo sreće zato što se ne zna kako će učenici reagirati i kakav će biti ishod na kraju. }\end{array}$ \\
\hline & $\begin{array}{l}\text { Tvrđava zato što je to većinom nemoguća misija zbog ogromne količine gradiva koju učenici s poteškoćama ne } \\
\text { mogu svladati. } \\
\text { Često jako neostvariva, zato što ponekad nedostaje potpore, razumijevanja i društvo kao da se nije ili ne želi } \\
\text { prilagoditi takvim problemima. } \\
\text { Da ih bacimo u vatru, ostali su učenici (najvjerojatnije) “normalni” i nemaju teškoća i onda će se taj učenik s } \\
\text { teškoćama osjećati izolirano i drugačije. } \\
\text { Preživljavanje miša okruženog mačkama, takvom djetetu je teško u okolini zdrave djece. } \\
\text { Utopija, ne provodi se kako bi trebalo. }\end{array}$ \\
\hline
\end{tabular}

iskažu vlastite kompetencije, napreduju i preuzmu odgovornost za sam proces i njegove ishode kako bi sva djeca ostvarila svoje pravo na najbolje moguće obrazovanje. U kategoriju Oblikovanje uvrštene su 
metafore usmjerene na sam inkluzivni proces koji se sastoji od ujedinjavanja mnogih dijelova u jedinstvenu cjelinu, sa sviješću o aktivnoj ulozi učitelja u tom procesu i doživljaju različitosti kao komponenti obrazovnog procesa koja ga obogaćuje. Kategorija Pružanje pomoći sadrži metafore u kojoj su naglašavane slabosti učenika s teškoćama u razvoju te isticana uloga učitelja koja se ponajviše odnosi na posebnu pomoć, pri čemu su učitelji često viđeni kao humane osobe koje pomažu slabijima. Slično je i s kategorijom Zaštita, gdje su grupirane metafore koje ukazuju na ranjivost učenika s teškoćama u razvoju, uz naglašavanje zaštitničke uloge učitelja koji su pozvani da štite i njeguju slabije učenike. Metafore svrstane u kategoriju Ulaganje napora ukazuju na pozitivne ishode inkluzivnog procesa, uz veliku požrtvovnost i trud učitelja koja u prethodnim kategorijama nije posebno naglašavana, dok kategorija Neizvjesnost uključuje metafore u kojima se naglašava neizvjesnost rezultata inkluzivnog procesa koji može, ali i ne mora, uroditi željenim ishodima. Pri tome nije jasna uloga učitelja jer se stječe dojam da rezultati ovise o nizu slučajnih i nepredvidivih okolnosti na koje učitelj ne može aktivno djelovati. Kategorija Uzaludan trud upućuje na negiranje inkluzivnog obrazovanja, bespomoćnost učitelja i učenika te izostanak potpore koja bi takav proces učinila smislenim i mogućim.

Analiza metafora o poučavanju učenika s teškoćama u razvoju (Poučavanje učenika s teškoćama u razvoju je ... zato što ...) je rezultirala istim kategorijama koje su slijedile jednaku logiku kao i prilikom grupiranja metafora o inkluziji učenika s teškoćama u razvoju. One su, zajedno s primjerima metafora koje ih sačinjavaju, prikazane u tablici 2 .

Podaci prikazani u tablicama 1 i 2 pokazuju da se uvjerenja studenata različitih godina učiteljskog studija i zaposlenih učitelja o inkluziji učenika s teškoćama protežu na kontinuumu od inkluzivnih do neinkluzivnih pristupa, pri čemu inkluzivnosti pridonosi usmjerenost na podržavanje, oblikovanje i pružanje pomoći učenicima s teškoćama. Zaštita i ulaganje napora kategorije su koje ukazuju na djelomično inkluzivna uvjerenja, budući da su temeljene na ograničenjima i teškoćama učenika i isticanju požrtvovnosti učitelja. Te metafore ukazuju na nedovoljnu svijest o počivanju inkluzivnog procesa na pravima, sposobnostima i interesima djece koja bi se trebala tretirati kao dio profesionalnog djelovanja svakog učitelja. Međutim, ovi sudionici istraživanja podržavaju inkluzivan proces. S druge strane, sudionici istraživanja koji su grupirani u kategorije Neizvjesnost i Uzaludan trud naglašavaju teškoće i prepreke koje prate odgojnoobrazovnu inkluziju, bez svijesti o mogućim vlastitim doprinosima kvaliteti inkluzivnog procesa, kao i bez prepoznavanja dobrobiti inkluzivne prakse za ukupnu zajednicu i same učenike s teškoćama.

Zastupljenost pojedinih uvjerenja među sudionicima ovog istraživanja prikazana je u tablici 3 .

Tablica 3. Odgovori ispitanika po kategorijama za ukupni uzorak $(\%, n=585)$

\begin{tabular}{|l|c|c|}
\hline Kategorije & $\begin{array}{c}\text { Inkluzija učenika } \\
\text { s teškoćama u } \\
\text { razvoju }\end{array}$ & $\begin{array}{c}\text { Poučavanje } \\
\text { učenika s } \\
\text { teškoćama u } \\
\text { razvoju }\end{array}$ \\
\hline Podržavanje & 39,1 & 24,2 \\
\hline Oblikovanje & 6,9 & 6,2 \\
\hline Pružanje pomoči & 4,1 & 7,1 \\
\hline Zaštita & 5,5 & 6,7 \\
\hline Ulaganje napora & 22,6 & 35,2 \\
\hline Neizvjesnost & 12,4 & 13,9 \\
\hline Uzaludan trud & 9,4 & 6,7 \\
\hline UKUPNO & $\mathbf{1 0 0}$ & $\mathbf{1 0 0}$ \\
\hline
\end{tabular}

Integralna analiza podataka u tablici 3 upućuje na zaključak da sudionici istraživanja iskazuju različita uvjerenja u odnosu na inkluziju i poučavanje učenika s teškoćama u razvoju. Pritom su uvjerenja povoljnija kada se radi o inkluziji, a nepovoljnija kada je u pitanju poučavanje ovih učenika. Navedeni zaključak proizlazi iz činjenice da su metafore o inkluziji gotovo polovice $(46 \%)$ ispitanika usmjerene na podržavanje inkluzivnog procesa, uz prepoznatljivu ulogu učitelja koja se najviše očituje u oblikovanju procesa odgoja i obrazovanja učenika. S druge strane, analiza metafora o poučavanju pokazala je da takva uvjerenja iskazuje tek trećina (30,4\%) studenata i učitelja. Uz poučavanje se većinski (49\%) vezuju djelomično inkluzivna uvjerenja koja su usmjerena na požrtvovnost, pružanje pomoći i zaštitu učenika s teškoćama. U toj su skupini metafora naglašene slabosti učenika i požrtvovnost učitelja, što je suprotno Konvenciji o pravima osoba s invaliditetom (2007) koja jasno upućuje na potrebu tretiranja kvalitetnog obrazovanja učenika s teškoćama kao jednog od temeljnih ljud- 
Tablica 2. Kategorije i primjeri metafora usmjerene na poučavanje učenika s teškoćama u razvoju

\begin{tabular}{|c|c|}
\hline \begin{tabular}{|l|} 
Kategorija \\
(tema)
\end{tabular} & ama u razvoju je ... zato što ... “ \\
\hline Podržavanje & $\begin{array}{l}\text { Dar zato što su takvi učenici najiskreniji i imaju najviše volje za radom. } \\
\text { Posao iz snova zato što vidjeti osmijeh i napredak učenika s teškoćama nam je najveća nagrada. } \\
\text { Umjetnost zato što treba znati poučavati i one pojedince koji fizički ili mentalno nisu na istoj razini kao i mi te } \\
\text { im dati do znanja da su prihvaćeni jednako kao i ostali. } \\
\text { Škola života zato što se susrećemo s različitostima i bez dijagnoze «učenika s teškoćama» u svakodnevnom } \\
\text { životu. } \\
\text { Joga zato što je to potvrda/pokazatelj kvalitete učitelja (stalno napredovanje). }\end{array}$ \\
\hline \begin{tabular}{|l|} 
Oblikovanje \\
\end{tabular} & $\begin{array}{l}\text { Brušenje kamena do dijamanta zato što i s učenicima koji imaju poteškoće možemo doći do napretka i poraditi } \\
\text { na njima. } \\
\text { Slagalica zato što je potrebno puno strpljenja i znanja kako bi se sve pravilno "posložilo". } \\
\text { Vrtlarenje, zato što treba znati kako i na koji način obraditi grm. } \\
\text { Pečenje kolača, zato što dodavanjem brojnih "sastojaka" situacija postaje bolja, ishod izvrstan, a svako novo } \\
\text { poučavanje prilika za dodavanje i mijenjanje isprobanog recepta. } \\
\text { Neobojeni crtež, zato što treba pomoć i suradnju u bojanju i ostvarenju cilja. }\end{array}$ \\
\hline & $\begin{array}{l}\text { Čitanje dobre knjige zato što se osjećate ispunjeno pomažući drugima. } \\
\text { Pružanje ruke osobi u moru koja ne zna dobro plivati, zato što je svaki učenik vrijedan i bez obzira na teškoće } \\
\text { treba nečiju ruku, podršku, ohrabrenje. } \\
\text {... je kao zvijezda padalica zato što im pomaže u ostvarivanju njihovih potreba. } \\
\text { Volonterski rad, pomažeš iako nisi imao drugi izbor. } \\
\text { Pružanje potrebne pomoći, djetetu puno znači, a i učitelju kad vidi rezultate. }\end{array}$ \\
\hline Zaštita & $\begin{array}{l}\text { Melem na djetetovu ranu, tim je učenicima naročito potrebna pažnja i davanje važnosti, da se i oni osjećaju } \\
\text { bitnim - i da razviju samopoštovanje. } \\
\text { Uzgajanje cvijeća, zato što moramo biti strpljivi da polaže svoje lijepe latice, a kad mu ne zadovoljimo uvjete, } \\
\text { ono neće napredovati. } \\
\text { Briga o vrtu, zato što ga je potrebno stalno zalijevati pažnjom, trudom, brigom, ljubavlju, sigurnošću, srećom, } \\
\text { znanjem. } \\
\text { Njegovati psa bez jedne noge, zato što ćemo ga jednako voljeti, poštivati i truditi se osmisliti što više načina da } \\
\text { razvije sve svoje sposobnosti. } \\
\text { Je kao njegovanje krhkog cvijeta zato što treba imati volje, pažnje i strpljenja da cvijet procvate. }\end{array}$ \\
\hline $\begin{array}{l}\text { Ulaganje } \\
\text { napora }\end{array}$ & $\begin{array}{l}\text { Putovanje po makadamu zato što je unatoč tome što sporije napreduje nego poučavanje učenika bez teškoća, } \\
\text { način na koji se također dođe do cilja. } \\
\text { Nebrušeni dijamant zato što tek kasnije, napornim radom i trudom možemo doći do nekih rezultata. } \\
\text { Uspon na planinu, zato što na nekim dijelovima može biti teško, ali kada se uspnemo, osjećamo ponos. } \\
\text { Rubikova kocka zato što je teško, ali zanimljivo. } \\
\text { Trčanje maratona zato što je ponekad jako teško ali kada uspijemo odnosno dođemo do cilja osjećamo se } \\
\text { ponosno. }\end{array}$ \\
\hline \begin{tabular}{|l|} 
Neizvjesnost \\
\end{tabular} & $\begin{array}{l}\text { Proljetno čišćenje zato što nikada ne znaš što treba reći, poučiti učenike a što ne. } \\
\text { Put u nepoznato zato što može imati uspješne ishode, a također i neuspješne. } \\
\text { Prah zato što se znanje prenosi jednako i na jednog i na drugog učenika, kako će oni to znanje "upiti” to je } \\
\text { osobna stvar. } \\
\text { Otvaranje poklona zato što nikada ne znamo što nas očekuje. } \\
\text { Hodanje po užetu zato što nikada nisi siguran kako će rezultirati slijedeći korak. }\end{array}$ \\
\hline $\begin{array}{l}\text { Uzalu } \\
\text { trud }\end{array}$ & $\begin{array}{l}\text { Naučiti dijete rolanju (ono koje ima problem s ravnotežom) zato što bez obzira koliko ono to želi i trudi, ne } \\
\text { može naučiti jer ima nešto što ga u tome sputava. } \\
\text { Sizifov posao zato što stalno treba vračati na početak i ponovo objasniti isto gradivo učeniku s teškoćama. } \\
\text { Nemoguća misija zato što takvi učenici (s teškoćama u razvoju) često bivaju neprihvaćeni od strane ostalih učenika. } \\
\text { Posuda bez dna zato što oni zahtijevaju puno više osnovnog znanja uz svo gradivo; postoji mogućnost da } \\
\text { većinu stvari zaborave ili ne shvate. } \\
\text {... je kao let bez krila zato što bez stručnih suradnika teško dođe do napretka djeteta. }\end{array}$ \\
\hline
\end{tabular}

skih prava, nasuprot pristupu koji se temelji na solidarnosti, humanosti i/ili milosrđu. Takva uvjerenja su u metaforama vezanima uz inkluziju prepoznata kod trećine $(32,2 \%)$ sudionika istraživanja. 
Neinkluzivne stavove koje karakterizira isticanje neizvjesnosti i uzaludnosti uloženih napora u inkluziju i poučavanje učenika s teškoćama iskazuje petina sudionika ovog istraživanja, što je razmjerno nepovoljan pokazatelj mogućnosti uspješnosti inkluzivnog odgojno-obrazovnog procesa. Naime, 21,8\% studenata i učitelja ne prepoznaje mogućnosti i korisnost odgojno-obrazovne inkluzije, a 20,6\% poučavanje učenika s teškoćama u razvoju povezuje sa slučajnostima ili uzaludnošću.

Nedvojbeno je da profesionalno djelovanje počiva na iskazanim uvjerenjima. Ona u većoj ili manjoj mjeri podržavaju inkluzivan proces, pa bi iskustvo i razina obrazovanja trebala voditi višoj razini usvojenosti inkluzivnih uvjerenja. Je li tome tako, pokazuje usporedba zastupljenosti pojedinih kategorija vezanih uz inkluziju i poučavanje učenika s teškoćama u četiri skupine sudionika ovog istraživanja (tablice 4 i 5).

Sudeći prema rezultatima prikazanima u tablici 4 i rezultatima $\chi^{2}$ testa, između četiri skupine ispitanika postoje statistički značajne razlike u uvje- renjima koja se tiču odgojno-obrazovne inkluzije. Studenti prve godine ističu se po iznadprosječnoj zastupljenosti uvjerenja koja upućuju na neinkluzivne stavove, upućujući na neizvjesnost i uzaludnost ulaganja napora u inkluzivan proces, te na djelomično inkluzivna uvjerenja koja se temelje na stavu o potrebi zaštite učenika s teškoćama $u$ razvoju (s obzirom na njihov pretpostavljeni inferioran status). Studente treće godine studija više od prosjeka karakteriziraju inkluzivna uvjerenja temeljena na podržavanju inkluzivnog procesa, ali i isticanje potrebe ulaganja dodatnih napora učitelja radi postizanja željenih ishoda inkluzije. Zanimljivo, uvjerenja skupine studenata pete godine učiteljskog studija su izrazito diferencirana, s blagom tendencijom nešto više zastupljenosti studenata koji podržavaju inkluziju (s usmjerenošću na oblikovanje učenika i inkluzivnog procesa), ili je podržavaju samo djelomično (s usmjerenošću na pružanje pomoći učenicima s teškoćama u razvoju i potrebu ulaganja dodatnih napora u uspješnost inkluzije). Zaposlene učitelje u odnosu na studente u znatno većoj mjeri nalazimo među sudionicima

Tablica 4. Usporedba zastupljenosti uvjerenja pojedinih skupina sudionika istraživanja vezanih za inkluziju učenika s teškoćama u razvoju $(\%, n=585)$

\begin{tabular}{|l|c|c|c|c|}
\hline Kategorije & Studenti 1. godine & Studenti 3. godine & Studenti 5. godine & Zaposleni učitelji \\
\hline Podržavanje & 22,1 & $\mathbf{4 1 , 7}$ & 17,1 & 19,1 \\
\hline Oblikovanje & 22,9 & 31,4 & $\mathbf{2 0 , 0}$ & 25,7 \\
\hline Pružanje pomoći & 14,3 & 33,3 & $\mathbf{1 9 , 0}$ & $\mathbf{3 3 , 3}$ \\
\hline Zaštita & $\mathbf{3 2 , 1}$ & 32,1 & 10,7 & $\mathbf{2 5 , 0}$ \\
\hline Ulaganje napora & 17,4 & $\mathbf{4 6 , 1}$ & $\mathbf{1 9 , 1}$ & 17,4 \\
\hline Neizvjesnost & $\mathbf{3 1 , 7}$ & 17,5 & 17,5 & $\mathbf{3 3 , 3}$ \\
\hline Uzaludan trud & $\mathbf{3 9 , 6}$ & 8,3 & 12,5 & $\mathbf{3 9 , 6}$ \\
\hline UKUPNO & $\mathbf{2 5 , 6}$ & $\mathbf{3 3 , 2}$ & $\mathbf{2 3 , 3}$ \\
\hline \multicolumn{4}{||}{$\chi^{\mathbf{2}}$ test $\mathbf{4 6 , 3 9 3 ;} \mathbf{p}=\mathbf{, 0 0 0}$} \\
\hline
\end{tabular}

Tablica 5. Usporedba zastupljenosti uvjerenja pojedinih skupina sudionika istraživanja vezanih za poučavanje učenika s teškoćama u razvoju $(\%, n=585)$

\begin{tabular}{|l|c|c|c|c|}
\hline KATEGORIJE & Studenti 1. godine & Studenti 3. godine & Studenti 5. godine & Zaposleni učitelji \\
\hline Podržavanje & 19,0 & $\mathbf{4 0 , 1}$ & 16,8 & $\mathbf{2 4 , \mathbf { 1 }}$ \\
\hline Oblikovanje & 25,7 & $\mathbf{5 1 , 4}$ & 14,3 & 8,6 \\
\hline Pružanje pomoći & $\mathbf{3 0 , 0}$ & 25,0 & $\mathbf{2 2 , 5}$ & 22,5 \\
\hline Zaštita & 15,8 & $\mathbf{4 4 , 7}$ & $\mathbf{2 1 , 1}$ & 18,4 \\
\hline Ulaganje napora & $\mathbf{3 5 , 0}$ & 28,5 & 15,5 & 21,0 \\
\hline Neizvjesnost & 19,0 & $\mathbf{3 5 , 4}$ & $\mathbf{2 2 , 8}$ & 22,8 \\
\hline Uzaludan trud & 18,4 & $\mathbf{7 , 9}$ & 21,1 & $\mathbf{5 2 , 6}$ \\
\hline UKUPNO & $\mathbf{2 5 , 6}$ & $\mathbf{3 3 , 2}$ & $\mathbf{1 8 , 0}$ & $\mathbf{2 3 , 3}$ \\
\hline \multicolumn{7}{|c|}{$\chi^{\mathbf{2} \text { test }=\mathbf{5 0 , 8 6 6 ;} \mathbf{p}=, \mathbf{0 0 0}}$} \\
\hline
\end{tabular}


istraživanja koje karakteriziraju neinkluzivna uvjerenja (neizvjesnost i uzaludan trud) te djelomično inkluzivna uvjerenja, osobito ona koja ističu potrebu pružanja pomoći učenicima s teškoćama $u$ razvoju radi njihove uspješne uključenosti u obrazovni proces.

Rezultati prikazani u tablici 5 odnose se na uvjerenja studenata različitih godina studija i zaposlenih učitelja prema poučavanju učenika s teškoćama u razvoju. Vrijednost i značajnost $\chi^{2}$ testa pokazuje da se četiri skupine ispitanika međusobno statistički značajno razlikuju i u uvjerenjima o poučavanju učenika s teškoćama. Studente prve godine studija relativno češće nalazimo među onima čija su uvjerenja djelomično inkluzivna, a temelje se na isticanju potrebe pružanja pomoći i ulaganju napora učitelja radi postizanja povoljnih učinaka inkluzije. Studenti treće godine su iznadprosječno zastupljeni među ispitanicima koji podržavaju inkluzivan proces, uključujući i svijest o ulozi učitelja koja je usmjerena oblikovanju iskustava učenja tih učenika. Oni istovremeno iznadprosječno iskazuju uvjerenja koja upućuju na potrebu zaštite učenika s teškoćama, kao i na neizvjesnost ishoda inkluzivnog procesa. Ova skupina studenata ujedno je najmanje zastupljena među onima koji negiraju smisao inkluzivnog procesa, ističući njegovu uzaludnost. Studenti pete godine studija dominantno su usmjereni na potrebu pružanja pomoći i zaštitu učenika s teškoćama u razvoju, a nešto češće su zastupljeni i u grupi ispitanika usmjerenih na neizvjesnost inkluzivnog procesa koja se temelji na nedovoljnoj razini svijesti o mogućnostima i potrebi aktivnog djelovanja učitelja u tom procesu. Zaposleni učitelji su prepoznatljivi po iznadprosječnoj zastupljenosti u skupini koja naglašava uzaludnost truda, ali i u skupini koja podržava inkluzivan proces.

Sumarno, uočljivo je da se studenti treće godine učiteljskog studija u uzroku ovog istraživanja ističu kao skupina koja više od drugih manifestira inkluzivna uvjerenja, dok se zaposleni učitelji ističu po nepovoljnijim i manje inkluzivnim uvjerenjima. Posljedica je to većeg broja čimbenika, među kojima važno mjesto pripada brojnim teškoćama vezanima uz provedbu odgojno-obrazovne inkluzije u redovnim školama. U tom smislu Romstein i Sekulić-Majurec (2015) s pravom ističu kako se suvremenim tumačenjem inkluzije djeci s teškoćama u razvoju i dalje negira mogućnost ravnopravne društvene participacije, jer ih se zapravo pasivno uvodi u okružje koje su za njih pripremile i kojega kontroliraju osobe bez teškoća, održavajući svojevrsnu prikrivenu ekskluziju, bez razumne prilagodbe i učinkovitih mjera potpore - kako djeci i roditeljima djece $s$ teškoćama u razvoju, tako i samim učiteljima.

Iako u sve četiri skupine sudionika istraživanja postoje različita uvjerenja, od inkluzivnih do izrazito neinkluzivnih, zastupljenost pojedinih uvjerenja u skupinama studenata različitih godina studija upućuje na nedovoljno jasne ishode inicijalnog obrazovanja učitelja u odnosu na razvoj njihovog profesionalnog identiteta koji bi inkluzivnu komponentu obrazovanja u većoj mjeri uvažio kao sastavni dio kvalitetnog profesionalnog djelovanja. Ukupno gledano, studenti treće godine imaju uvjerenja o inkluziji i poučavanju učenika s teškoćama koja su primjerenija znanstvenim spoznajama i strateškim opredjeljenjima od mlađih i starijih kolega. Moguće je pretpostaviti da je ovaj nalaz povezan s obrazovnim iskustvom tijekom studija. Naime, u prve tri godine studija studenti su uključeni u kolegije koji su povezani sa suvremenim inkluzivnim pristupima učenju i poučavanju, s naglaskom na kolegij koji se specifično odnosi na inkluzivnu pedagogiju, te strategije i pristupe poučavanju i učenju djece s teškoćama što doprinosi razvoju njihovih profesionalnih uvjerenja. Završne godine učiteljskog studija u većoj su mjeri usmjerene metodičkim kolegijima, a pitanje je u kojoj mjeri metodike u obzir uzimaju potrebu individualizacije učenja i poučavanja, s obzirom na potrebe učenika s teškoćama.

Navedeno je u skladu s ranijim istraživanjima koja ukazuju na razlike u samoprocjenama kompetencija studenata i zaposlenih učitelja za odgoj i obrazovanje učenika s teškoćama, pri čemu studenti iskazuju višu razinu kompetencija za identifikaciju učenika s teškoćama, iniciranje aktivnosti za afirmaciju njihovih prava, kao i u socijalizaciji učenika s teškoćama, a učitelji za planiranje i provedbu individualiziranih odgojno-obrazovnih programa (Kudek Mirošević, 2016). Istraživanja upućuju i na malu spremnost učitelja za preuzimanjem odgovornosti za kvalitetu inkluzivnog procesa (Peček, 
Čuk i Lesar, 2008) te sklonost učitelja da negativno procjenjuju i vrednuju specifične kategorije učenika (Namrata, 2011).

Budući da je doprinos inicijalnog obrazovanja i praktičnog iskustva na profesionalna uvjerenja studenata i zaposlenih učitelja o učenicima s teškoćama u razvoju razmjerno slab, nameće se potreba za vrednovanjem inicijalnog i cjeloživotnog obrazovanja učitelja, imajući u vidu način na koji obrazovanje pridonosi razvoju kompetencija za razumijevanje prava i potreba učenika s teškoćama u razvoju, kao i strategija poučavanja koje pridonose većoj inkluzivnosti odgoja i obrazovanja. Sudeći prema rezultatima ovog istraživanja, takvi bi obrazovni programi uz razvoj profesionalnih znanja i vještina, u većoj mjeri trebali biti usmjereni razvoju profesionalnih uvjerenja učitelja.

\section{ZAKLJUČAK}

Problem ovog istraživanja bio je odgovoriti na pitanje mijenjaju li se i na koji način uvjerenja studenata učiteljskog studija i zaposlenih učitelja o poučavanju učenika s teškoćama u razvoju i njihovoj inkluziji u odgojno-obrazovni proces, pomoću utvrđivanja uvjerenja studenata različitih godina studija i zaposlenih učitelja o inkluziji učenika s teškoćama te analize razlika u uvjerenjima između studenata prve, treće i pete godine učiteljskog studija te zaposlenih učitelja.

Istraživanje je temeljeno na transverzalnom pristupu koji ima ograničenja u interpretaciji konceptualnih promjena u smislu razvoja individualnih profesionalnih uvjerenja studenata kroz studijski program. Nadalje, istraživanje je isključivo usmjereno na interpretaciju metafora, bez uvida u okolnosti koje su mogle pridonijeti sadržaju metafora (npr. uspjeh u studiju, iskustvo u obrazovanju učenika s teškoćama u razvoju, uvjeti u kojima rade zaposleni učitelji i slično).

Ipak, temeljem rezultata ovog istraživanja moguće je sugerirati neke zaključke jer se interpretacija rezultata temelji na činjenici da se sva tri poduzorka studenata školuju prema istim uvjetima, to jest prema istom studijskom programu, a zaposleni učitelji rade u školama unutar istog (hrvatskog) obrazovnog sustava.
U istraživanju se krenulo od pretpostavke da inicijalno obrazovanje i praktičan rad $\mathrm{s}$ djecom $\mathrm{s}$ teškoćama pridonosi profesionalnim uvjerenjima o odgojno-obrazovnoj inkluziji. Rezultati omogućuju zaključak da studenti i učitelji većinski iskazuju inkluzivna uvjerenja koja karakterizira podržavanje inkluzivnog procesa i svijest o značajnoj ulozi učitelja u tom procesu. Radi se o uvjerenjima u kojima se odgoj i obrazovanje učenika s teškoćama u razvoju tumači kao sastavni dio učiteljske profesije, a učitelji su primarno doživljeni kao oblikovatelji iskustava učenja. Među sudionicima ovog istraživanja znatno su zastupljena i djelomično inkluzivna uvjerenja koja su u većoj mjeri usmjerena na slabe strane učenika s teškoćama koji iziskuju zaštitu i pomoć učitelja. Kako bi učitelj očekivanu zaštitu i pomoć i osigurao, nužno je ulaganje izuzetnog napora učitelja. Iako učenici s teškoćama u razvoju zaista u odnosu na tipično razvijene učenike iziskuju primjerenu podršku i dodatan trud učitelja, inkluzivna uvjerenja uvažavaju i jake strane ovih učenika te ukazuju na mnogostruke koristi koje sudjelovanje učenika s teškoćama u razvoju donose ukupnoj zajednici, što u metaforama svrstanih u ove kategorije nije bilo moguće prepoznati. Petinu ispitanika karakteriziraju neinkluzivna uvjerenja, usmjerena isticanju uzaludnosti ulaganja napora $i$ karakterizirana izostankom svijesti o povezanosti aktivnog kompetentnog djelovanja učitelja i ishoda inkluzivnog procesa učenika. Općenito, sudionici istraživanja u većoj mjeri podržavaju inkluzivan proces no što je to slučaj sa samim poučavanjem učenika s teškoćama u razvoju, uz što vezuju veće i raznovrsnije izazove.

Prva specifična hipoteza ovog istraživanja $\left(\mathrm{H}_{1}\right)$ jest da zaposleni učitelji u usporedbi sa studentima imaju uvjerenja koja su u većoj mjeri usklađena sa znanstvenim spoznajama i strateškim preporukama o inkluziji učenika s teškoćama u redovne škole. Rezultati, međutim, ne upućuju na mogućnost prihvaćanja ove hipoteze jer je svaka skupina ispitanika zastupljena u određenim kategorijama metafora koje upućuju na inkluzivna uvjerenja, a zaposleni učitelji se ističu po većoj zastupljenosti u skupini ispitanika koja ukazuje na uzaludnost ulaganja truda u inkluzivno obrazovanje.

Sljedećom specifičnom hipotezom $\left(\mathrm{H}_{2}\right)$ je pretpostavljeno da studenti viših godina studija u uspo- 
redbi s mlađim kolegama imaju uvjerenja koja su u većoj mjeri usklađena sa znanstvenim spoznajama i strateškim preporukama o inkluziji učenika s teškoćama u redovne škole. Ni ovu hipotezu nije moguće jednoznačno prihvatiti, budući da se po inkluzivnim uvjerenjima ističu studenti treće godine, dok su uvjerenja studenata pete godine o poučavanju učenika s teškoćama usporediva s predprofesionalnim uvjerenjima studenata prve godine učiteljskog studija, a ujedno se upravo studenti završne godine studija međusobno znatno razlikuju s obzirom na odnos prema inkluziji.

Prema tome, pokazalo se da inicijalno obrazovanje učitelja nije dovoljno usmjereno razvoju uvjerenja studenata koji bi znatnije pridonijeli kvaliteti inkluzivne prakse što pridonosi održavanju svih teškoća s kojima je proces odgojno-obrazovne inkluzije suočen u obrazovnim sustavima svih suvremenih društava i sve izraženijim raspravama o nedostižnosti ideala inkluzivnog obrazovanja (npr. Slee i Alla, 2011; Hornby, 2014; Romstein i Sekulić-Majurec, 2015). Unatoč prihvaćanju inkluzivnih vrijednosti, sam inkluzivan proces još uvijek nije primjereno implementiran u odgojnoobrazovne ustanove, uključujući i sustav visokog obrazovanja učitelja i nastavnika. Inkluzija učenika s teškoćama u razvoju u pravilu nije popraćena primjerenom individualizacija odgojno-obrazovnog procesa i okruženja te resursima podrške roditeljima, učenicima i učiteljima, a postojeće inicijalno obrazovanje učitelja nedovoljno pridonosi pripremljenosti studenata za suočavanje sa svim izazovima inkluzivne prakse.

Prema tome, ovo je istraživanje jedno u nizu istraživanja koji upućuju na nespremnost studenata učiteljskog studija i zaposlenih učitelja za inkluzivnu praksu, što se u literaturi ističe kao jedna od osnovnih prepreka inkluzivnom obrazovanju (npr. Spratt i Florian, 2013; Sharma i Loreman, 2014; Skočić-Mihić i sur, 2014; Bouillet i Bukvić, 2015; Kudek Mirošević, 2016; Gluhak i Bouillet, 2017 i drugi). 


\section{LITERATURA}

Batarelo Kokić, I., Vukelić, A., Ljubić, M. (2009): Mapiranje politika i praksi za pripremu nastavnika za inkluzivno obrazovanje u kontekstima socijalne i kulturalne raznolikosti: Izvješće za Hrvatsku. Bologna: European Training Foundation.

Beauchamp, C., Lynn, T. (2009): Understanding teacher identity: an overview of issues in the literature and implications for teacher education. Cambridge Journal of Education, 39, 2, 175-189. doi: 10.1080/03057640902902252.

Bouillet, D., Bukvić, Z. (2015): Razlike u mišljenjima studenata i zaposlenih učitelja o obrazovnoj inkluziji učenika s teškoćama. Hrvatska revija za rehabilitacijska istraživanja. 51, 1, 9-23.

Bouillet, D., Kudek Mrošević, J. (2015): Students with Disabilities and Challenges in Educational Practice. Hrvatski časopis za odgoj i obrazovanje, 17, 2, 11-26.

Brajković, S., Milinović, N. (2015). Obrazovanje za društvenu pravdu. Zagreb: Pučko otvoreno učilište Korak po korak.

Braun, V., Clarke, V. (2006): Using thematic analysis in psychology. Qualitative Research in Psychology, 3, 2, 77-101. doi: 10.1191/147808870qp063oa.

Dmitrović, P. (2011): Preduvjeti za primjenu inkluzije. Metodički obzori, 6, 3, 69-82.

Domović, V. (2006): Profesionalne kompetencije studenata nastavničkih fakulteta i predmetnih nastavnika. Metodika - časopis za teoriju i praksu metodika u predškolskom odgoju, školskoj i visokoškolskoj izobrazbi, 7, 12, 43-52.

Domović, V. (2011): Učiteljska profesija i profesionalni identitet učitelja. U: Vizek Vidović, V. (ur.): Učitelji i njihovi mentori (str. 12-37). Zagreb: Institut za društvena istraživanja

Domović, V., Vizek Vidović, V. (2013): Understanding the role of teachers, pupils and teaching - Beliefs of students at the Faculty of Teacher Education.Sociologija i prostor, 51, 3, 493-508.

Domović, V., Vizek Vidović, V., Bouillet, D. (2017): Student teachers' beliefs about the teacher's role in inclusive education. European Journal of Special Needs Education, 32, 2, 175-190. doi: 10.1080/08856257.2016.1194571

Farkas, A. (2014): Conceptualizing Inclusive Education and Contextualizing it within the UNICEF Mission. New York: United Nations Children's Fund - UNICEF.

Feiman-Nemser, S. (2001): From preparation to practice: Designing continuum to strenghten and sustain teaching. Teachers College Record. 103, 6, 1013-1055.

Forlin, Ch. (2012): Respodning to the Need for Inclusive Teacher Education: Rhetoric or Reality? U: Forlin, Ch. (ur.): Future Directions for Inclusive Teacher Education, (str. 3-12). New York: Routledge.

Gluhak, I., Bouillet, D. (2017): Usklađenost inicijalnog obrazovanja učitelja s potrebama odgojno-obrazovne inkluzije. U: Bouillet, D., Đuranović, M., Tot, D. (ur.): Zbornik odabranih radova s 11. međunarodnoga balkanskog kongresa obrazovanja i znanosti Budućnost obrazovanja i obrazovanje za budućnost, tematsko područje: Kvaliteta $i$ inkluzivnost obrazovanja - preduvjeti održive budućnosti, (str. 139- 162). Zagreb: Učiteljski fakultet Sveučilišta u Zagrebu.

Hornby, G. (2014): Inclusive Special Education. New York: Springer.

Igrić, Lj., Cvitković, D., Wagner Jakab, A. (2009): Djeca s teškoćama učenja u interaktivnom sustavu obitelj-školavršnjaci. Hrvatska revija za rehabilitacijska istraživanja, 45, 1, 31-38.

Ivančić, Đ., Stančić, Z. (2013): Stvaranje inkluzivne kulture škole. Hrvatska revija za rehabilitacijska istraživanja, 49, 2, 139-157.

Karamatić Brčić, M. (2013): Pretpostavke o inkluziji i školi. Život i škola, 59, 30, 67-78.

Konvencija o pravima djeteta (1990.). Službeni list - Međunarodni ugovori 15/90; Narodne novine - Međunarodni ugovori 12/93.; 20./97.

Konvencija o pravima osoba s invaliditetom UN-a. Narodne novine 6/07; 3/08; 5/08. 
Kudek Mirošević, J. (2016): Procjene kompetentnosti studenata učiteljskog studija i učitelja za inkluzivnu praksu. Hrvatski časopis za odgoj i obrazovanje, 18(Sp.Ed.) 1, 71-86. doi: 10.15516/cje.v18i0.2181

Miles, S. (2007): Škola za sve - Uključivanje djece s razvojnim smetnjama u obrazovanje. Podgorica: Save The Children UK.

Namrata, E. (2011). Teachers' beliefs and expectations towards marginalized children in classroom setting: a qualitative analysis. Procedia Social and Behavioral Science, 15, 850-853.

Okvir za poticanje i prilagodbu iskustava učenja te vrednovanje postignuća djece i učenika s teškoćama. Posjećeno 20. 09. 2016. na mrežnoj stranici: http://www.kurikulum.hr/wp-content/uploads/2016/02/Okvir-djeca-i-ucenicis-teskocama.pdf

Pajares, M. F. (1992): Teachers' beliefs and educational research: cleaning up a messy construct. Review of educational research, 62, 3, $307-322$.

Peček, M., Čuk, I, Lesar, I. (2008). Teacher's perceptions of the inclusion of marginalised groups. Educational Studies, $34,3,225-239$.

Rogers, G. (2011): Learning-to-learn and learning-to-teach: the impact of disciplinary subject study on student-teachers' professional identity. Journal of Curriculum Studies, 43, 2, 249-268., doi: 10.1080/00220272.2010.521262.

Romstein, K., Sekulić-Majurec, A. (2015): Obrnuta inkluzija - pedagoške vrijednosti i potencijali. Pedagogijska istraživanja, 12, 1-2, 41-51.

Sharma, U., Loreman, T. (2014): Teacher Educator Perspectives on Systemic Barriers to Inclusive Education: an International Conversation. U: Jones, Ph. (ur): Bringing Insider Perspectives into Inclusive Teacher Learning, (str. 168-177). London \& New York: Routledge Taylor \& Francis Group.

Skočić Mihić, S. (2011): Spremnost odgajatelja i faktori podrške za uspješno uključivanje djece s teškoćama u rani predškolski odgoj i obrazovanje. Doktorska disertacija. Zagreb: Edukacijsko-rehabilitacijski fakultet Sveučilišta u Zagrebu.

Skočić Mihić, S., Lončarić, D., Kolombo, M., Perger, S., Nastić, M., Trgovčić, E. (2014): Samoprocijenjene kompetencije studenata učiteljskog studija za rad s djecom s posebnim odgojno-obrazovnim potrebama. Napredak, $154,3,303-322$.

Slee, R., Allan, J. (2011): Excluding the Included: A Reconsideration of Inclusive Education. International Studies in Sociology of Education, 11, 2, 173-192.

Spratt, J., Florian, L. (2013): Applying the Principles of Inclusive Pedagogy in Initial Teacher Education: from University Based Course to Classroom Action. Revista de Investigación en Educatión, 11, 3, 133-140.

Sutherland, L., Markauskaite, L. (2012): Examining the role of authenticity in supporting the development of professional identity: an example from teacher education. Higher Education, 64, 6, 747-766. doi: 10.1007/s10734012-9522-7.

Vizek Vidović, V. (2005): Cjeloživotno obrazovanje učitelja i nastavnika: višestruke perspective. Zagreb: Institut za društvena istraživanja u Zagrebu.

Zeichner, K., Gore, J. (1990): Teacher Socialisation. U: Houston, W. R. (ur.): Handbook of Research on Teacher Education, (str. 329-348). New York: MacMillan.

Zheng, H. (2009): A review of research on EFL pre-Service teachers` beliefs and practices. Journal of Cambrige Studies. 4, 1, $73-81$.

Zrilić, S. (2011): Djeca s posebnim potrebama u vrtiću i nižim razredima osnovne škole. Zadar: Sveučilište u Zadru.

Zrilić, S., Brzoja, K. (2013): Promjene u pristupima odgoju i obrazovanju učenika s teškoćama. Magistra Iadertina, $8,1,141-153$. 


\section{BELIEFS ABOUT INCLUSIVE PRACTICES AMONG STUDENTS OF TEACHER EDUCATION AND IN-SERVICE TEACHERS}

Abstract: Beliefs refer to a set of conceptual images that include general knowledge about phenomena, people and events related to the professional context. The focus of this paper was on establishing differences in the beliefs of first-, third-and fifthyear students in teacher education and employed teachers regarding educational inclusion and teaching pupils with developmental disabilities. Its purpose was to provide answers to the question of whether and to what extent the beliefs of different groups of respondents vary with regard to pupils with developmental disabilities and their inclusion in the educational process.

The participants in the research were 585 student teachers and teachers employed in primary schools in the Republic of Croatia. Beliefs were explored by means of the metaphor technique, using a familiar object or event as a mental vehicle for interpreting complex notions or situations. The participants in the research were asked to complete the sentences 'Inclusion of pupils with developmental disabilities is like ..., because ...' and 'Teaching pupils with developmental disabilities is like ..., because ...'.

It could be established that in the total sample most participants expressed inclusive beliefs, since their responses were directed at shaping and supporting pupils with developmental disabilities. However, when it came to the teaching process, the share of participants expressing inclusive beliefs decreased.

Inclusive beliefs characterised third-year students, who were at the time of the investigation completing a course in inclusive education, to the greatest extent and in-service teachers to the smallest extent. The remaining groups of students shared almost identical professional beliefs, which points to an insufficient contribution of both initial teacher education and teaching experience to the transformation from pre-professional towards professional beliefs about inclusive education.

Keywords: inclusive education, pupils with developmental disabilities, initial teacher education, teachers, beliefs, metaphor 